\title{
Soil Health Improvement by Addition the Manure and Compost for Peanut Plant (Arachis Hypogaea L) in Leranwetan, Palang, Tuban
}

\author{
Lukdatul Wardah ${ }^{1}$, Sugeng Prijono ${ }^{2}$, and Zaenal Kusuma ${ }^{2 *}$ \\ ${ }^{1}$ Student of Postgraduate, Study Program of Management of Land and Water, Faculty of Agriculture, University \\ of Brawijaya, Malang \\ ${ }^{2}$ Lecturer on the Department of Agricultural soil, Faculty of Agriculture, University of Brawijaya, Malang
}

\begin{abstract}
The content of organic matter in the soil is one of the factors that contribute in determining the success of cultivation agricultural. This is because organic matter can increase the fertility of the chemical, physical and biological soil. Determination of organic matter content is done based on the number of $C$ organic. The low organic matter in the soil is because of the intensive agricultural system. Soil conditions in Palang has very low C-organic content, the average is less than $1 \%$. The C-organic content less than $1 \%$ of the soil cannot provide sufficient nutrients, in addition to the nutrients supplied by manure are unable to be handled by the soil components so easily leached, decreased cation exchange capacity, weakening the soil aggregation, micro nutrients easily leached and decreased the power of water binding. Through the addition of organic matter, the soil structure that was weight becomes relatively lighter crumb. Vertical water movement or infiltration can be improved and the soil can absorb water more quickly so that minimizing runoff and erosion. As well as with soil aeration to be better because the soil pore space (porosity) increases due to the formation of aggregates. The addition of organic matter to the soil is in the form of compost litter and cow manure.

The results of this study are the results after the addition of organic matter such as cow manure and compost litter. The highest C-organic content of the soil is in the treatment P6 (cow manure) by $1.46 \%$, while the highest production in the treatment $P 3$ (compost litter) was $16.58 \mathrm{~kg}$.

The suggestions that could be addressed in this study are the need for increasing doses of cow manure and compost litter to improve C-organic content of the soil. There need to research on the effect of a combination of cow manure and compost litter in improving the soil fertility in the aspect of chemical, physical and biological soil.
\end{abstract}

Key words: low c-organic, additional organic matter, compost litter, cow manure

\section{Introduction}

Soil conditions in Palang has very low $\mathrm{C}$-organic content, the average is less than $1 \%$. The $\mathrm{C}$-organic content less than $1 \%$ of the soil cannot provide sufficient nutrients, in addition to the nutrients supplied by manure are unable to be handled by the soil components so easily leached, decreased cation exchange capacity, weakening the soil aggregation, micro nutrients easily leached and decreased the power of water binding. Through the addition of organic matter, the soil structure that was weight becomes relatively lighter crumb. Vertical water movement or infiltration can be improved and the soil can absorb water more quickly so that minimizing runoff and erosion. As well as with soil aeration to be better because the soil pore space (porosity) increases due to the formation of aggregates.

Organic matter have a much greater influence on the land than the mineral content in the soil, either on the physical, chemical and biological soil. The ability of soil to retain water as one of the physical nature of the soil is affected by organic matter in the soil.

But the influence of organic matter on the amount of available water, the vast majority occur indirectly through its influence on soil porosity (Brady dan Buckman, 2002).

According to Wongso (2003), addition of organic matter in soil will increase the ability of soil to hold water so that increase the ability to provide water for plant growth. This has been proven by the addition of manure in Andisol is able to increase the pore holds water by $4.73 \%$ (from $69.8 \%$ to $73.1 \%$ ). In clay soil by adding organic matter will increase soil infiltration as a result of the increasing meso pores and decreasing micro pores of the soil.

The ability of soil to hold water can vary considerably from one place to another place, which is caused by different organic matter content. The provision of organic matter in soil to increase soil's ability to hold water is determined by the quantities and types of organic matter applied.

The addition of organic matter to the soil can be composted litter and cow manure. The result of Suwardjono's research (2001) showed that the organic fertilizer such as manure can increase the number of pods 
filled in peanuts. Other than manure application can increase the availability of nutrients, it can also improve physical nature of the soil. The use of organic matter not only increase the availability of nutrients for plants, but also create appropriate conditions for the plant to improve aeration, root penetration easier and improve the water holding capacity (BOA, 2008).

\section{Research Method}

There are several steps that done in this research. After the survey, the next step is a laboratory analysis about soil's health indicators from the aspects of soil chemistry, soil physics, and soil biology.

After doing field survey and laboratory analysis, then the assessment from the results (scoring). This scoring process is based on soil health assessment from the Cornell University and using modifications based on the Criteria of Soil Chemistry by Hardjowigeno (1985) for some parameters that are not available on soil health assessment from the Cornell University.

By the scoring results on sampling of the observation which produces soil fertility class with medium criteria that has very low $\mathrm{C}$-organic content below $1 \%$, hence the need for improvement by the addition of organic matter, which is expected to improve soil fertility especially in improving $\mathrm{C}$-organic content in the soil by application the type of organic matter such as compost litter and manure. The addition of organic matter in this study is in the form of cow manure and compost litter, by the addition of organic matter is expected to increase the availability of C-organic content in the soil.

The treatment will be carried out in this study is presented in Table 1.

Table 1. Treatment and code used in research

\begin{tabular}{cccc}
\hline No & code & \multicolumn{1}{c}{ Treatment } & Dosage $\left(\mathrm{Kg} \mathrm{plot}^{-1}\right)$ \\
1 & Soil / control & Without fertilizer \\
2 & P1 & Soil + Leave manure & $0,8 \mathrm{~kg}^{*}$ \\
3 & P2 & Soil + Leave manure & $1,94 \mathrm{~kg}^{* *}$ \\
4 & P3 & Soil + Leave manure & $3,08 \mathrm{~kg}^{* * *}$ \\
5 & P4 & Soil + cow manure & $0,94 \mathrm{~kg}^{* * * *}$ \\
6 & P5 & Soil + cow manure & $2,37 \mathrm{~kg}^{* * * * *}$ \\
7 & P6 & Soil + cow manure & $3,77 \mathrm{~kg}^{* * * * * *}$ \\
\hline
\end{tabular}

Keterangan :

$\begin{array}{ll}* & =\text { Equivalent to the provision of organic material 3,9 } \mathrm{th}^{-1} \\ * * & =\text { Equivalent to the provision of organic material 9,5 } \mathrm{ha}^{-1} \\ * * * & =\text { Equivalent to the provision of organic material 15,09 } \mathrm{ha}^{-1} \\ * * * * & =\text { Equivalent to the provision of organic material 4,7 } \mathrm{ha}^{-1} \\ * * * * * & =\text { Equivalent to the provision of organic material } 11,6 \mathrm{th} \mathrm{h}^{-1} \\ * * * * * * & =\text { Equivalent to the provision of organic material } 18,4 \mathrm{ha}^{-1} \\ \text { the size of plot } & =3 \mathrm{~m} \times 3 \mathrm{~m}=6 \mathrm{~m}^{2}\end{array}$

This study used a randomized block design (RAK) by 7 treatments were repeated 3 times, so it takes twenty-one pieces of experimental plots. The data has been obtained and tested by analysis of variance or ANOVA by level of $5 \%$ to determine the effect of treatment. To compare differences in the effect of each treatment followed by Duncan's test 5\%.

\section{Findings And Discussions}

After doing field survey and laboratory analysis, then the assessment from the results (scoring). This scoring process is based on soil health assessment from the Cornell University.

Tabel 2. Final results scoring location before in doing repairs soil health

\begin{tabular}{|c|c|c|c|}
\hline \multicolumn{4}{|c|}{ CORNEL SOIL HEALTH TEST REPORT (COMPREHENSIVE) } \\
\hline \multirow{2}{*}{\multicolumn{2}{|c|}{$\begin{array}{l}\text { Location : first point } \\
\text { Crops Grown : groundnut }\end{array}$}} & \multirow{2}{*}{\multicolumn{2}{|c|}{$\begin{array}{l}\text { Agent :FP-UB } \\
\text { Date Sampled : 24-05-2013 }\end{array}$}} \\
\hline & & & \\
\hline Aspec & Indicator & Value & Score \\
\hline \multirow{3}{*}{ PHYSICAL } & Available Water Capacity $(\mathrm{m} / \mathrm{m})$ & 0.35 & 64 \\
\hline & Surface Bulk Density $\left({\left.\mathrm{g} . \mathrm{cm}^{-3}\right)}^{-}\right.$ & 1.25 & 83 \\
\hline & Subsurface Bulk Density $\left(\mathrm{g} . \mathrm{cm}^{-3}\right)$ & 1.52 & 64 \\
\hline \multirow{3}{*}{ BIOLOGICAL } & Organic Matter (\%) & 0.32 & 6 \\
\hline & Total Nitrogen $(\%)$ & 0.05 & 30 \\
\hline & $\mathrm{pH}$ & 6.89 & 100 \\
\hline \multirow{4}{*}{ CHEMICAL } & $\mathrm{P}(\mathrm{ppm})$ & 7.97 & 100 \\
\hline & $\mathrm{K}\left(\mathrm{me} 100 \mathrm{~g}^{-1}\right)$ & 0.58 & 85 \\
\hline & $\mathrm{Ca}\left(\mathrm{me} 100 \mathrm{~g}^{-1}\right)$ & 31.46 & 84 \\
\hline & 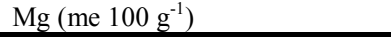 & 5.99 & 71 \\
\hline
\end{tabular}


explanation: red: Low, yellow : Medium, green: High

From the results of the scoring table above, each parameter influences to Overall Quality Score (OQS). Before doing the improvement of soil health has a value 68.7 , if included to soil health class will be included in the criteria of the medium.

From the results of the scoring table shows that the issues raised in the area of research in the terms of its biological nature is the content of C-organic of the soil is very low with a content of $0.32 \%$, and the content of N-total of the soil is $0.05 \%$ which included to the health of the soil is very low. While in the physical properties of the available water content by $0.35 \mathrm{~m} / \mathrm{m}$ and soil density by $1.52 \mathrm{~g} . \mathrm{cm}-3$ and classified in the medium soil health. By the problems occurred, and then in this study will add the organic matter such as compost litter and cow manure which aims to improve the oil health in the research area.

\section{The Influence of Soil Health Improvement by Addition Compost Litter and Cow Manure on the Growth of Peanut Plant}

Plant growth is influenced by the natures of soil fertility i.e. physical fertility, chemical and biological. If the physical fertility more emphasis the condition of its physical that has related with the supplying water and air of the soil, then the chemical fertility related to problems of the availability of nutrients for plant growth.

Tabel 3. Condition after increase cow manure

\begin{tabular}{|c|c|c|c|}
\hline \multicolumn{4}{|c|}{ CORNEL SOIL HEALTH TEST REPORT (COMPREHENSIVE) } \\
\hline \multirow{2}{*}{\multicolumn{2}{|c|}{$\begin{array}{l}\text { Location : Repair with cow manure } \\
\text { Crops Grown : groundnut }\end{array}$}} & \multirow{2}{*}{\multicolumn{2}{|c|}{$\begin{array}{l}\text { Agent :FP-UB } \\
\text { Date Sampled : 24-05-2013 }\end{array}$}} \\
\hline & & & \\
\hline Aspec & Indicator & Value & Score \\
\hline \multirow{3}{*}{ PHYSICAL } & Available Water Capacity $(\mathrm{m} / \mathrm{m})$ & 0.30 & 59 \\
\hline & Surface Bulk Density $\left(\mathrm{g} \mathrm{cm}^{-3}\right)$ & 1.13 & 78 \\
\hline & Subsurface Bulk Density $\left({\mathrm{g} . \mathrm{cm}^{-3}}^{-3}\right.$ & 1.21 & 57 \\
\hline \multirow{3}{*}{ BIOLOGICAL } & Organic Matter $(\%)$ & 1.46 & 15 \\
\hline & Total Nitrogen $(\%)$ & 0.21 & 40.56 \\
\hline & $\mathrm{pH}$ & 7.01 & 100 \\
\hline \multirow{4}{*}{ CHEMICAL } & $\mathrm{P}(\mathrm{ppm})$ & 9.19 & 100 \\
\hline & $\mathrm{K}\left(\mathrm{me} 100 \mathrm{~g}^{-1}\right)$ & 1.12 & 92 \\
\hline & $\mathrm{Ca}\left(\mathrm{me} 100 \mathrm{~g}^{-1}\right)$ & 30.68 & 82 \\
\hline & $\mathrm{Mg}\left(\mathrm{me}_{\left.100 \mathrm{~g}^{-1}\right)}\right.$ & 3.62 & 65 \\
\hline \multicolumn{2}{|c|}{ OVERALL QUALITY SCORE } & & 68,86 \\
\hline
\end{tabular}

explanation: red: Low, yellow : Medium, green: High

Tabel 4. Condition after increase leave manure

\begin{tabular}{|c|c|c|c|}
\hline \multicolumn{4}{|c|}{ CORNEL SOIL HEALTH TEST REPORT (COMPREHENSIVE) } \\
\hline \multirow{2}{*}{\multicolumn{2}{|c|}{$\begin{array}{l}\text { Location : repair with leave manure } \\
\text { Crops Grown : groundnut }\end{array}$}} & \multirow{2}{*}{\multicolumn{2}{|c|}{$\begin{array}{l}\text { Agent :FP-UB } \\
\text { Date Sampled : 24-05-2013 }\end{array}$}} \\
\hline & & & \\
\hline Aspec & Indicator & Value & Score \\
\hline \multirow{3}{*}{ PHYSICAL } & Available Water Capacity (m/m) & 0.29 & 58 \\
\hline & Surface Bulk Density $\left(\mathrm{g} \cdot \mathrm{cm}^{-3}\right)$ & 1.11 & 77 \\
\hline & Subsurface Bulk Density $\left(\mathrm{g} . \mathrm{cm}^{-3}\right)$ & 1.19 & 55 \\
\hline \multirow{3}{*}{ BIOLOGICAL } & Organic Matter (\%) & 0.89 & 11 \\
\hline & Total Nitrogen $(\%)$ & 0.20 & 40,47 \\
\hline & $\mathrm{pH}$ & 7.01 & 100 \\
\hline & $\mathrm{P}(\mathrm{ppm})$ & 10.14 & 100 \\
\hline \multirow{3}{*}{ CHEMICAL } & $\mathrm{K}\left(\mathrm{me} 100 \mathrm{~g}^{-1}\right)$ & 0.88 & 90 \\
\hline & $\mathrm{Ca}\left(\mathrm{me} 100 \mathrm{~g}^{-1}\right)$ & 30.49 & 82 \\
\hline & $\mathrm{Mg}\left(\mathrm{me} 100 \mathrm{~g}^{-1}\right)$ & 3.68 & 64 \\
\hline \multicolumn{2}{|c|}{ OVERALL OUALITY SCORE } & & 67,75 \\
\hline
\end{tabular}

explanation: red: Low, yellow : Medium, green: High

From the results of the scoring table above, each parameter influences to Overall Quality Score (OQS). Before doing the improvement of soil health has a value 68.7 , if included to soil health class will be included in the criteria of the medium, it's also after doing improvement by addition the organic matter in the form of compos litter (68.86) and cow manure (67.75) if included to soil health class will be included in the criteria of the medium. The result of Overall Quality Score, the result of Survey dan laboratory Analysis presented on Tabel 33. 
Tabel 5. Result Overall Quality Score, Survey and laboratory analysis

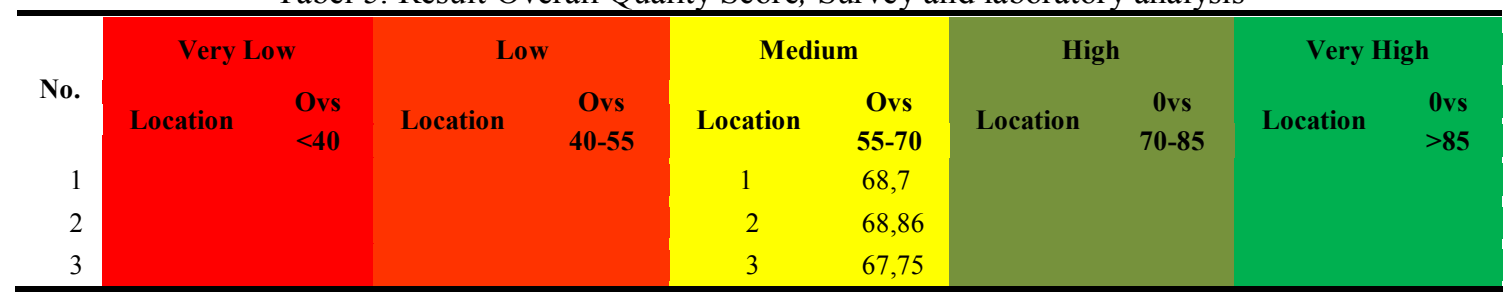

explanation: $\quad$ 1: before repairing

2: reapair with leave manure

3: Repair with cow manure

From the results of Overall Quality Score above, before and after the improvement by the addition of organic matter such as compost litter and cow manure has not changed and remains at the health class in medium scale. This is possible caused of less in providing doses in addition of organic matter such as compost litter and cow manure.

According to Mowidu (2001), giving 20-30 tonnes / ha of organic matter has significant effect in increasing the total porosity, amount of pore is useful, amount of pore moisture storage and aggregate stability and reduce the density of particles, lumps density and permeability. From the results from Anggraeni's research (2006) showed that the composting of organic litter 20 ton.kg-1 is able to increase the level of soil mineral nitrogen from $26.41 \mathrm{mg} . \mathrm{kg}-1$ to $206.62 \mathrm{mg} . \mathrm{kg}-1$ or increasing by $682 \%$ with no planting treatment. Composting is also able to improve the physical nature of the soil.

\section{The Influence in Improving of Soil Health by an addition Cow Manure and Compost on Physical Nature of Soil \\ Water Content}

Based on the analysis of variance showed that dosing compost litter and cow manure significantly affected the water content depth of $10 \mathrm{~cm}$ at each phase of the peanut plant growth.

Table 6. Average Effect of litter and Manure Compost Cow Manure Against Moisture Depth $10 \mathrm{~cm}$.

\begin{tabular}{ccccc}
\hline Treatment & \multicolumn{2}{c}{ Water content $10 \mathrm{~cm}$} & \\
P0 & Phase 1 & Phase 2 & $0.32 \mathrm{a}$ & Phase 4 \\
P1 & $0.31 \mathrm{a}$ & $0.35 \mathrm{a}$ & $0.35 \mathrm{~b}$ & $0.33 \mathrm{a}$ \\
P2 & $0.33 \mathrm{ab}$ & $0.37 \mathrm{c}$ & $0.38 \mathrm{~b}$ & $0.38 \mathrm{~b}$ \\
P3 & $0.34 \mathrm{c}$ & $0.39 \mathrm{c}$ & $0.39 \mathrm{c}$ & $0.40 \mathrm{c}$ \\
P4 & $0.37 \mathrm{~d}$ & $0.36 \mathrm{~b}$ & $0.37 \mathrm{~b}$ & $0.42 \mathrm{~cd}$ \\
P5 & $0.33 \mathrm{bc}$ & $0.38 \mathrm{c}$ & $0.39 \mathrm{c}$ \\
P6 & $0.35 \mathrm{~d}$ & $0.40 \mathrm{c}$ & $0.39 \mathrm{~b}$ & $0.42 \mathrm{~cd}$ \\
\hline
\end{tabular}

Explanation : digits that have the same notation in the same column are not significantly different according to Duncan at level $\alpha=5 \%$

In general, the mean value of the water content the soil depth of $10 \mathrm{~cm}$ on the various treatment time increases by the growth phase. The increase of the soil water content at a depth of $10 \mathrm{~cm}$ due to the presence of organic matter derived from compost litter and cow manure into the soil. The content of the soil water content at the end of observation tends to increase compared to the initial planting.

\section{Weight of Contents}

The results of variance analysis showed that treatment the doses of cow manure and compost litter significantly affected to the observation to weight content of the soil at various growth phases Peanuts.

Table 7. Average Effect of litter and Manure Compost Cow Manure Against Land Fill Weight

\begin{tabular}{cllll}
\hline \multirow{2}{*}{ Treatment } & \multicolumn{4}{c}{ Soil bulk density $\left({\left.\mathrm{g} . \mathrm{cm}^{-3}\right)}\right)$} \\
& Phase 1 & Phase 2 & Phase 3 & Phase 4 \\
P0 & $1.2 \mathrm{c}$ & $1.24 \mathrm{e}$ & $1.25 \mathrm{~d}$ & $1.26 \mathrm{c}$ \\
P1 & $1.22 \mathrm{~d}$ & $1.21 \mathrm{~d}$ & $1.17 \mathrm{c}$ & $1.14 \mathrm{~b}$ \\
P2 & $1.19 \mathrm{bc}$ & $1.18 \mathrm{c}$ & $1.15 \mathrm{bc}$ & $1.13 \mathrm{ab}$ \\
P3 & $1.17 \mathrm{a}$ & $1.16 \mathrm{a}$ & $1.13 \mathrm{a}$ & $1.11 \mathrm{a}$ \\
P4 & $1.2 \mathrm{c}$ & $1.18 \mathrm{c}$ & $1.16 \mathrm{bc}$ & $1.13 \mathrm{ab}$ \\
P5 & $1.19 \mathrm{bc}$ & $1.18 \mathrm{bc}$ & $1.15 \mathrm{bc}$ & $1.14 \mathrm{~b}$ \\
P6 & $1.18 \mathrm{ab}$ & $1.16 \mathrm{ab}$ & $1.14 \mathrm{ab}$ & $1.13 \mathrm{ab}$ \\
\hline
\end{tabular}


Explanation : digits that have the same notation in the same column are not significantly different according to Duncan at level $\alpha=5 \%$

In general, the mean value of the content weight of the soil at various treatment to be lower along with increasing the growth phase of peanut. This could be due to the influence of soil organic matter content. The provision of organic matter such as compost litter or cow manure into the soil, the longer it will decompose and produce humus. Humus plays a role in binding the soil particles in the soil aggregation process, so it can change the composition of the soil solids. By the change in the soil volume that getting lighter, so that influence on weight content of the soil. It is appropriate with the statement of Thamrin (2000) that the organic matter is porous, when applied to the soil will create pore space in the soil so that the weight content of soil getting down. Stable soil pore space makes it easy water flows down and absorbed by the soil matrix thus the ability of the soil to hold water can be increased

Density

The treatment of compost litter and cow manure has significantly affect to the observation of soil density in the growth phase of peanut.

Table 8. Average Effect of litter and Manure Compost Cow Manure Soil Against Gravity

\begin{tabular}{ccccc} 
Treatment & \multicolumn{4}{c}{ Density of land $\left(\mathrm{g} . \mathrm{cm}^{-3}\right)$} \\
P0 & Phase 1 & Phase 2 & Phase 3 & Phase 4 \\
P1 & $2.55 \mathrm{a}$ & $2.49 \mathrm{a}$ & $2.3 \mathrm{a}$ & 2.57 \\
P2 & $3.16 \mathrm{~b}$ & $2.79 \mathrm{~b}$ & $2.54 \mathrm{~b}$ & 2.35 \\
P3 & $3.31 \mathrm{~d}$ & $2.85 \mathrm{bc}$ & $2.72 \mathrm{c}$ & 2.63 \\
P4 & $3.23 \mathrm{c}$ & $3.06 \mathrm{~cd}$ & $2.77 \mathrm{~cd}$ & 2.62 \\
P5 & $3.31 \mathrm{~d}$ & $2.98 \mathrm{bcd}$ & $2.81 \mathrm{~cd}$ & 2.69 \\
P6 & $3.3 \mathrm{~d}$ & $3.05 \mathrm{~cd}$ & $2.87 \mathrm{~cd}$ & 2.72 \\
& $3.29 \mathrm{~d}$ & $3.1 \mathrm{~d}$ & $2.91 \mathrm{~d}$ & 2.76
\end{tabular}

Explanation : digits that have the same notation in the same column are not significantly different according to Duncan at level $\alpha=5 \%$

The average value of soil density on compost litter treatment and cow manure were significantly different and were not significantly different at each growth phase of peanut. Provision of compost litter and cow manure generally has significant effect on decrease of density and significantly different if compared with controls. This is because of to improve the weight of contents and soil density, required considerable time. In general, the mean value of soil density on various treatments getting lower with longer observation due to the addition of compost litter and cow manure. It is possible the influence from the addition of organic matter. In accordance with the statement from Arifin (2011), that the soil density influenced by the various materials constituent grains of soil, if the soil material is controlled by the organic matter then the soil density will getting smaller.

\section{The Influence of Soil Health Improvement by Addition of Manure and Compost on Biological Nature of the Soil \\ C-organic Soil}

The treatment of compost litter and cow manure significantly affect to the observation of C-organic soil in the growth phase of peanut.

Table 9. Average Effect of litter and Manure Compost Cow Manure Against Soil C-Organic

\begin{tabular}{cllll}
\multirow{2}{*}{ Treatment } & \multicolumn{4}{c}{ Soil C-Organic (\%) } \\
Phase 1 & Phase 2 & Phase 3 & Phase 4 \\
P0 & $0.61 \mathrm{c}$ & $0.47 \mathrm{a}$ & $0.36 \mathrm{a}$ & $0.24 \mathrm{a}$ \\
P1 & $0.42 \mathrm{~b}$ & $0.58 \mathrm{ab}$ & $0.69 \mathrm{~b}$ & $0.81 \mathrm{~b}$ \\
P2 & $0.3 \mathrm{a}$ & $0.42 \mathrm{a}$ & $0.83 \mathrm{bc}$ & $0.89 \mathrm{bc}$ \\
P3 & $0.52 \mathrm{c}$ & $0.7 \mathrm{bc}$ & $0.92 \mathrm{bc}$ & $0.69 \mathrm{~b}$ \\
P4 & $0.52 \mathrm{c}$ & $0.68 \mathrm{bc}$ & $0.89 \mathrm{bc}$ & $1.26 \mathrm{~cd}$ \\
P5 & $0.6 \mathrm{c}$ & $0.78 \mathrm{bc}$ & $1 \mathrm{bc}$ & $1.36 \mathrm{~d}$ \\
P6 & $0.71 \mathrm{~d}$ & $0.85 \mathrm{c}$ & $1.08 \mathrm{c}$ & $1.46 \mathrm{~d}$
\end{tabular}

Explanation : digits that have the same notation in the same column are not significantly different according to Duncan at level $\alpha=5 \%$

It is appropriate with the statement by Syukur and Indah (2006), that the addition of organic fertilizer to the soil in the form of compost or manure, it caused an increase C-organic content in the soil. The more organic fertilizer added to the soil, the more $\mathrm{C}$-organic content released into the soil. It also affects to the improvement of soil organic matter. The low mean content of soil organic matter in the P0 treatment was because of no 
addition of organic matter in the form of compost litter and cow manure. Without the addition of organic matter supplied to the soil, the $\mathrm{C}$-organic was released into the soil is not exist. In general, an increase of C-organic in the soil due to the presence of organic matter from compost litter and cow manure into the soil. C-organic content at the end of the observation tends to increase if compared with the initial planting. This is because organic matter has hydrolysis process thus become organic matter dissolved in the water. Then had acidification process that turns organic matter into organic acids, $\mathrm{H} 2$ and $\mathrm{CO} 2$ were carried out by bacteria acidification. Then turn into organic acids acetate $(\mathrm{CH} 3 \mathrm{COOH})$ and $\mathrm{H} 2$ by bacterium acetogenesis. Acetate and $\mathrm{H} 2$ had methane fermentation by methane bacteria into $\mathrm{CH} 4$ and $\mathrm{CO} 2$ which is volatile (Siregar, 2005).

\section{N-total Soil}

The treatment compost litter and cow manure significantly affect the N-total soil observations on the growth phase of peanut.

Table 10. Average Effect of litter and Manure Compost Cow Manure N-total Against Land

\begin{tabular}{cllll}
\multirow{2}{*}{ Treatment } & \multicolumn{4}{c}{ Soil N-Total (\%) } \\
& Phase 1 & Phase 2 & Phase 3 & Phase 4 \\
P0 & $0.13 \mathrm{ab}$ & $0.14 \mathrm{a}$ & $0.15 \mathrm{a}$ & $0.17 \mathrm{a}$ \\
P1 & $0.12 \mathrm{a}$ & $0.14 \mathrm{a}$ & $0.16 \mathrm{a}$ & $0.17 \mathrm{ab}$ \\
P2 & $0.13 \mathrm{~b}$ & $0.15 \mathrm{a}$ & $0.18 \mathrm{~b}$ & $0.19 \mathrm{~cd}$ \\
P3 & $0.16 \mathrm{~cd}$ & $0.17 \mathrm{bc}$ & $0.19 \mathrm{c}$ & $0.2 \mathrm{de}$ \\
P4 & $0.13 \mathrm{ab}$ & $0.15 \mathrm{a}$ & $0.17 \mathrm{~b}$ & $0.18 \mathrm{bc}$ \\
P5 & $0.15 \mathrm{c}$ & $0.16 \mathrm{~b}$ & $0.19 \mathrm{c}$ & $0.2 \mathrm{cde}$ \\
P6 & $0.16 \mathrm{~d}$ & $0.18 \mathrm{c}$ & $0.2 \mathrm{c}$ & $0.21 \mathrm{e}$
\end{tabular}

Explanation : digits that have the same notation in the same column are not significantly different according to Duncan at level $\alpha=5 \%$

$\mathrm{N}$-total soil mean value in the treatment of compost litter and cow manure significantly affected at each growth phase of peanut. Provision of compost litter and cow manure generally has significant effect on N-total of soil and significantly different compared with P0 (control). The use of compost litter and cow manure can increase N-total although it is relatively small. At the beginning of research N-total in the soil is in very low criteria but relatively getting up on level to be low criteria after the treatment, and after the harvest period $\mathrm{N}$ total content of the soil was also unchanged. According to Hardjowigeno (2004), the causes of losings $\mathrm{N}$ in the soil is it used by plants for growth, where the increasing age of the plant, the needs of the plants to nutrients will be increased so that the taking nutrients both ammonium and nitrate from the soil is increasing.

\section{The Influence of Soil Health Improvement by Addition of Manure and Compost on Chemical Nature of} the Soil

\section{Phosphor (P)}

The treatment of compost litter and cow manure significantly affect to the observation of Phosphor in the growth phase of peanut.

Table 11. Average Effect of litter and Manure Compost Cow Manure P Against Land

\begin{tabular}{cllll} 
Treatment & \multicolumn{4}{c}{ Soil phosphorus (ppm) } \\
& Phase 1 & Phase 2 & Phase 3 & Phase 4 \\
P0 & $6.64 \mathrm{a}$ & $7.74 \mathrm{ab}$ & 8.12 & $8.97 \mathrm{~b}$ \\
P1 & $7.74 \mathrm{~d}$ & $8.14 \mathrm{c}$ & 8.97 & $9.82 \mathrm{~b}$ \\
P2 & $8.14 \mathrm{e}$ & $8.98 \mathrm{~d}$ & 9.74 & $10 \mathrm{a}$ \\
P3 & $8.98 \mathrm{f}$ & $9.68 \mathrm{e}$ & 6.99 & $10.14 \mathrm{a}$ \\
P4 & $6.9 \mathrm{ab}$ & $7.5 \mathrm{a}$ & 8.37 & $9.07 \mathrm{~b}$ \\
P5 & $7.08 \mathrm{~b}$ & $7.78 \mathrm{ab}$ & 8.58 & $9.13 \mathrm{~b}$ \\
P6 & $7.41 \mathrm{c}$ & $8.02 \mathrm{bc}$ & 8.87 & $9.19 \mathrm{~b}$
\end{tabular}

Explanation : digits that have the same notation in the same column are not significantly different according to Duncan at level $\alpha=5 \%$

The mean value of phosphor in the treatment of compost litter and cow manure is significantly different at each growth phase of peanut. Provision of compost litter and cow manure generally has significant effect on phosphor and significantly different compared with P0 (control). Generally, the increase of Phospor in the soil caused by the availability of organic matter derived from compost litter and cow manure into the soil. The content of Phosphor at the end of the observation tends to increase compared with the initial planting. Furthermore, Brady and Weil (2002) states in organic matter (compost) is one source of N, P, and S. 


\section{Potassium (K)}

The treatment of compost litter and cow manure significantly affect to the observation of potassium in the growth phase of peanut.

Table 12. Effect of litter and Manure Compost Cow Manure Against Soil Potassium

\begin{tabular}{cllll} 
Treatment & \multicolumn{4}{c}{ potassium soil $\left(\mathrm{me.g}^{-1}\right)$} \\
& Phase 1 & Phase 2 & Phase 3 & \multicolumn{1}{c}{ Phase 4} \\
P0 & $0.48 \mathrm{a}$ & $0.55 \mathrm{a}$ & $0.65 \mathrm{a}$ & $0.76 \mathrm{a}$ \\
P1 & $0.52 \mathrm{ab}$ & $0.6 \mathrm{ab}$ & $0.7 \mathrm{a}$ & $0.8 \mathrm{a}$ \\
P2 & $0.56 \mathrm{bc}$ & $0.64 \mathrm{ab}$ & $0.74 \mathrm{a}$ & $0.86 \mathrm{ab}$ \\
P3 & $0.59 \mathrm{c}$ & $0.67 \mathrm{~b}$ & $0.75 \mathrm{a}$ & $0.88 \mathrm{abc}$ \\
P4 & $0.68 \mathrm{~d}$ & $0.82 \mathrm{c}$ & $0.9 \mathrm{~b}$ & $1.04 \mathrm{bcd}$ \\
P5 & $0.74 \mathrm{~d}$ & $0.89 \mathrm{c}$ & $0.99 \mathrm{~b}$ & $1.12 \mathrm{~d}$ \\
P6 & $0.75 \mathrm{~d}$ & $0.9 \mathrm{c}$ & $0.98 \mathrm{~b}$ & $1.07 \mathrm{~cd}$
\end{tabular}

Explanation : digits that have the same notation in the same column are not significantly different according to Duncan at level $\alpha=5 \%$

In general, the increase of potassium in the soil caused by the availability of organic matter derived from compost litter and cow manure into the soil. The content of potassium at the end of the observation tends to increase compared with the initial planting.

\section{Calcium (Ca)}

The treatment of compost litter and cow manure significantly affect to the observation of calcium in the growth phase of peanut. The mean value of calcium in the treatment of compost litter and cow manure is significantly different at each growth phase of peanut. Provision of compost litter and cow manure generally has significant effect on calcium and significantly different compared with P0 (control).

Table 13. Average Effect of litter and Manure Compost Cow Manure Soil Against Ca

\begin{tabular}{cllll}
\hline \multirow{2}{*}{ Treatment } & \multicolumn{4}{c}{ calcium land $\left(\mathrm{me.g}^{-1}\right)$} \\
& Phase 1 & Phase 2 & Phase 3 & Phase 4 \\
P0 & $28.29 \mathrm{a}$ & $28.46 \mathrm{a}$ & $28.53 \mathrm{a}$ & $28.64 \mathrm{a}$ \\
P1 & $28.87 \mathrm{~b}$ & $29.3 \mathrm{~b}$ & $29.76 \mathrm{~b}$ & $30.08 \mathrm{~b}$ \\
P2 & $29.47 \mathrm{c}$ & $29.95 \mathrm{c}$ & $30.19 \mathrm{bc}$ & $30.38 \mathrm{bc}$ \\
P3 & $29.86 \mathrm{~cd}$ & $30.22 \mathrm{c}$ & $30.33 \mathrm{c}$ & $30.49 \mathrm{c}$ \\
P4 & $29.75 \mathrm{~cd}$ & $30.16 \mathrm{c}$ & $30.33 \mathrm{c}$ & $30.5 \mathrm{c}$ \\
P5 & $29.9 \mathrm{~cd}$ & $30.22 \mathrm{c}$ & $30.41 \mathrm{c}$ & $30.55 \mathrm{c}$ \\
P6 & $30.14 \mathrm{~d}$ & $30.38 \mathrm{c}$ & $30.52 \mathrm{c}$ & $30.68 \mathrm{c}$ \\
\hline
\end{tabular}

Explanation : digits that have the same notation in the same column are not significantly different according to Duncan at level $\alpha=5 \%$

the increase of calcium value in the soil caused by the availability of organic matter derived from compost litter and cow manure. The increasing value of calcium can increase the availability of another nutrients and improve the physical nature of the soil, by increasing the nutrient and physical nature of the soil then the growth of plant will be better (Sumaryo and Suryono, 2000).

In general, the increase of calcium in the soil caused by the availability of organic matter derived from compost litter and cow manure into the soil. The content of calcium at the end of the observation tends to increase compared with the initial planting.

\section{Magnesium (Mg)}

The treatment of compost litter and cow manure significantly affect to the observation of magnesium in the growth phase of peanut.

Table 14. Average Effect of litter and Manure Compost Cow Manure Against Soil Mg

\begin{tabular}{cllll} 
Treatment & \multicolumn{4}{c}{ magnesium soil $\left(\mathrm{me}^{-1} \mathrm{~g}^{-1}\right)$} \\
P0 & Phase 1 & Phase 2 & Phase 3 & Phase 4 \\
P1 & $3.13 \mathrm{a}$ & $3.19 \mathrm{a}$ & $3.25 \mathrm{a}$ & $3.3 \mathrm{a}$ \\
P2 & $3.29 \mathrm{c}$ & $3.36 \mathrm{~b}$ & $3.49 \mathrm{bc}$ & $3.51 \mathrm{~b}$ \\
P3 & $3.36 \mathrm{~d}$ & $3.4 \mathrm{bc}$ & $3.49 \mathrm{bc}$ & $3.61 \mathrm{~d}$ \\
P4 & $3.28 \mathrm{c}$ & $3.37 \mathrm{bc}$ & $3.58 \mathrm{~d}$ & $3.68 \mathrm{e}$ \\
P5 & $3.31 \mathrm{c}$ & $3.4 \mathrm{bc}$ & $3.49 \mathrm{bc}$ & $3.54 \mathrm{bc}$ \\
P6 & $3.32 \mathrm{c}$ & $3.43 \mathrm{~cd}$ & $3.53 \mathrm{~cd}$ & $3.62 \mathrm{~d}$
\end{tabular}

Explanation : digits that have the same notation in the same column are not significantly different according to Duncan at level $\alpha=5 \%$ 
The mean value of magnesium in the treatment of compost litter and cow manure is significantly different at each growth phase of peanut.

The higher of magnesium then the metabolism occur on the cell nucleus at its optimum, where magnesium is an essential element forming chlorophyll and play a role in system of enzim. Magnesium has a considerable influence on plant growth (Sastrosayono, 2005).

In general, the increase of magnesium in the soil caused by the availability of organic matter derived from compost litter and cow manure into the soil. The content of magnesium at the end of the observation tends to increase compared with the initial planting (Picture 15). The increasing of magnesium will influence to the growth and production of plants, because the role of magnesium include correcting soil acidity to match the $\mathrm{pH}$ of the required plant. Neutralizing the saturation of substances that poison the soil and plants when these substances are excessive as $\mathrm{Al}, \mathrm{Fe}$, and $\mathrm{Cu}$. The increasing of effectiveness and efficiency in absorption of nutrients has been available in the soil derived from organic matter (Rifqi, 2010).

\section{Conclusions}

Provision of cow manure and compost litter has good effects in improving the health of soil in the aspect of physical, chemical and biological. Provision of cow manure and composted litter can increase Corganic content and N-total content of the soil, and its also reduce weight content of the soil, density, porosity and water content of the soil. Application of organic fertilizer to the soil with low content of C-organic and Ntotal can improve the growth of peanut.

\section{Bibliography}

[1]. Arifin, Z. 2011. Analysis of Soil Quality Index Value Entisol in Different Land Use. Agroteksos 21 (1):47-54

[2]. BOA. 2008. Rescue Mother Earth Organic Farming. Denpasar: Bali Organic Association.

[3]. Brady, N. C. dan Harry O Buckman. 2002. Soil Science. Bhratara Karya Aksara Publisher. Jakarta.

[4]. Brady, N. C. and R. R. Weil. 2002. The Nature and Properties of Soils $13^{\text {th }}$ Edition. Wiley Eastern Limited. India

[5]. Debuyser dan Tessier. 2004. Soil Physical Properties Affected By Long-term Fertilization. Europ. J. Soil Sci. 55: 505-512.

[6]. Hardjowigeno, S. 1985. Soil Genesis and Classification. IPB Graduate School. Bogor

[7]. Mowidu. 2001. Role of Organic Matter and Clay Aggregates Against Aggregation and Pore Size on Entisol. Graduate Thesis. Gadjah Mada University. Yogyakarta.

[8]. Siregar, A.S. 2005, Waste Water Treatment Plant. Kanisius. Yogyakarta.

[9]. Thamrin,T. 2002. Composting Technique Coverage. Institute for Agricultural Technology South Sumatra.

[10]. Wongso Suntoro, 2003. Role of Organic Matter and Soil Fertility Against The management efforts. Speech Professor of Soil Fertility. Faculty of Agriculture. Eleven Maret University. 